J. Westerbacka $\cdot$ A. Cornér $\cdot$ K. Kannisto $\cdot$ M. Kolak $\cdot$ J. Makkonen · E. Korsheninnikova · T. Nyman ·

A. Hamsten · R. M. Fisher · H. Yki-Järvinen

\title{
Acute in vivo effects of insulin on gene expression in adipose tissue in insulin-resistant and insulin-sensitive subjects
}

Received: 18 April 2005 / Accepted: 1 September 2005 / Published online: 16 December 2005

(C) Springer-Verlag 2005

\begin{abstract}
Aims/hypothesis: We determined the response of selected genes to in vivo insulin in adipose tissue in 21 non-diabetic women. Materials and methods: The women were divided into insulin-sensitive and -resistant groups based on their median whole-body insulin sensitivity ( $8.7 \pm 0.4$ vs $4.2 \pm 0.3 \mathrm{mg} \mathrm{kg}^{-1} \mathrm{~min}^{-1}$ for insulin-sensitive vs -resistant group). Subcutaneous adipose tissue biopsies were obtained before and after 3 and 6 h of i.v. maintained euglycaemic hyperinsulinaemia. Adipose tissue mRNA concentrations of facilitated glucose transporter, member 1 ( $S L C 2 A 1$, previously known as GLUT1), facilitated glucose transporter, member 4 (SLC2A4, previously known as GLUT4), peroxisome proliferator-activated receptor $\gamma$ $(P P A R G)$, peroxisome proliferator-activated receptor $\gamma$ co-activator $1 \alpha(P P A R G C 1 A), 11 \beta$-hydroxysteroid dehydrogenase-1 (HSD11B1), TNF, adiponectin (ADIPOQ), IL6 and the macrophage marker $C D 68$ were measured using real-time PCR. Results: Basal expression of 'insulin-sensitivity genes' $S L C 2 A 4$ and $A D I P O Q$ was lower while that of 'insulin-resistance genes', HSDI1B1 and IL6 was significantly higher in the insulin-resistant than in the insulinsensitive group. Insulin significantly increased expression of 'insulin-sensitivity genes' SLC2A4, PPARG, PPARGC1A
\end{abstract}

J. Westerbacka $(\bowtie) \cdot$ A. Cornér · J. Makkonen .

E. Korsheninnikova $\cdot$ H. Yki-Järvinen

Department of Medicine, Division of Diabetes,

University of Helsinki,

P.O. Box 340, FIN-00029 HUCH,

Helsinki, Finland

e-mail: jukka.westerbacka@helsinki.fi

Tel.: +358-9-47171885

Fax: +358-9-47175585

K. Kannisto $\cdot$ M. Kolak · A. Hamsten

R. M. Fisher · H. Yki-Järvinen

Atherosclerosis Research Unit,

King Gustaf V Research Institute,

Karolinska Institute,

Stockholm, Sweden

T. Nyman

Minerva Research Institute,

Helsinki, Finland and $A D I P O Q$ in the insulin-sensitive group, while only expression of PPARG and PPARGC1A was increased in the insulin-resistant group. The expression of 'insulin-resistance genes' HSDI1BI and IL6 was increased by insulin in the insulin-resistant group, but insulin failed to increase $H S D 11 B 1$ expression in the insulin-sensitive group. At $6 \mathrm{~h}$, expression of $H S D 11 B 1, T N F$ and IL6 was significantly higher in the insulin-resistant than in the insulin-sensitive group. IL6 expression increased significantly more in response to insulin in the insulin-resistant than in the insulin-sensitive group. CD68 was overexpressed in the insulin-resistant as compared with the insulin-sensitive group at both 0 and $6 \mathrm{~h}$. Conclusions/interpretation: These data suggest that genes adversely affecting insulin sensitivity hyperrespond to insulin, while genes enhancing insulin sensitivity hyporespond to insulin in insulin-resistant human adipose tissue in vivo.

Keywords Adipocytokines - Adiponectin - Cortisol . Interleukin $\cdot$ Macrophages $\cdot$ PGC-1 $\cdot$ TNF

Abbreviations $A C T B$ : gene encoding $\beta$-actin ADIPOQ: gene encoding adiponectin - $H S D 11 B 1$ : gene encoding $11 \beta$-hydroxysteroid dehydrogenase-1 - PPARG: peroxisome proliferator-activated receptor $\gamma$.

PPARGC1A: peroxisome proliferator-activated receptor $\gamma$ co-activator $\alpha \cdot$ SLC2A1: facilitated glucose transporter, member $1 \cdot$ SLC2A4: facilitated glucose transporter, member $4 \cdot T B P$ : gene encoding TATA-box binding protein

\section{Introduction}

Low-grade systemic inflammation and insulin resistance frequently coexist. Serum concentrations of cytokines, such as IL6 [1-6] and in some studies TNF [6, 7] correlate with markers of insulin resistance. Adipose tissue is one site of inflammation in insulin-resistant conditions. The number of macrophages is increased in both obese and lipoatrophic insulin-resistant subjects [8-10], and the expression of genes encoding IL6 [2,6] and TNF $[2,6,7]$ is increased in human 
adipose tissue. IL6 impairs insulin signalling in 3T3-L1 adipocytes in vitro [11], and adipose tissue IL6 content correlates inversely with insulin action in vivo in humans [12]. The increased $T N F$ expression in adipose tissue was recently suggested to originate exclusively from macrophages [8].

Insulin-resistant adipose tissue also overexpresses other genes that possibly contribute to insulin resistance, e.g. the gene encoding the enzyme that converts cortisone to cortisol, $11 \beta$-hydroxysteroid dehydrogenase-1 (HSD11B1), which is expressed in both adipocytes and macrophages [13, 14]. Overexpression of this enzyme in mice results in insulin resistance and visceral obesity [15]. In addition to these 'insulin-resistance' genes, another set of genes ('insulinsensitivity genes') are underexpressed in insulin-resistant adipose tissue. These include the gene encoding adiponectin $(A D I P O Q)$, which is deficient in both serum and adipose tissue of obese [16-18] and lipoatrophic [19] subjects, as well as the genes encoding the insulin-sensitive facilitated glucose transporter, member 4 ( $S L C 2 A 4$, previously known as GLUT4) [20], the adipogenic transcription factor peroxisome proliferator-activated receptor- $\gamma(P P A R G)[21,22]$ and its coactivator $1 \alpha(P P A R G C 1 A)[23,24]$.

Regarding acute regulation of 'insulin-resistance' genes, insulin has been found to increase IL6 expression in vitro in human adipocytes [25] and in 3T3-L1 cells [26], and transiently in a study in vivo in human adipose tissue [27]. Data on $T N F$ expression are inconsistent, with one study reporting a transient increase in $T N F$ mRNA by insulin in vivo with no change in serum TNF [27], while another in vivo study [28] and one in vitro study using human adipose tissue [29] found no effect of insulin on TNF expression. Insulin has been reported to decrease $H S D 11 B 1$ expression in vitro [13], and not to change expression during a 3-h insulin infusion in human adipose tissue [28]. Insulin acutely increases SLC2A4 [30, 31] and PPARG [32] expression, but there are no in vivo data on acute regulation of PPARGC1A or ADIPOQ in vivo in human adipose tissue.

No studies to date have compared the acute effects of insulin on 'insulin-resistance' and '-sensitivity' genes in insulin-resistant and -sensitive subjects. In the present study, we compared expression of selected 'insulin-resistance' genes (IL6, TNF, HSD11B1) and 'insulin-sensitivity' genes (SLC2A4, PPARG, PPARGCIA, ADIPOQ) in subcutaneous adipose tissue biopsies of insulin-sensitive and insulin-resistant subjects, and compared responses of these genes to acute hyperinsulinaemia by repeating the biopsies after 3 and $6 \mathrm{~h}$ of insulin infusion. We also determined whether expression of the macrophage marker CD68 is increased in the insulin-resistant vs -sensitive subjects, and whether its expression is regulated by insulin.

Subjects, materials and methods

Subjects and study designs A total of 21 non-diabetic apparently healthy Caucasian women were recruited on the basis of the following inclusion criteria: (1) age 18-60 years, and (2) no known acute or chronic disease other than obesity based on history and physical examination and standard laboratory tests (blood counts, serum creatinine, thyroidstimulating hormone, electrolyte concentrations and electrocardiogram). Other exclusion criteria included pregnancy and treatment with drugs that may alter glucose tolerance. In each subject, whole-body insulin sensitivity was measured using the euglycaemic insulin clamp technique (insulin infusion rate $1 \mathrm{mU} \mathrm{kg}^{-1} \mathrm{~min}^{-1}$ for $6 \mathrm{~h}$ ) and needle biopsies of adipose tissue were taken before and after 3 and $6 \mathrm{~h}$ of hyperinsulinaemia. The women were divided into insulinsensitive $(n=11)$ and insulin-resistant $(n=10)$ groups, on the basis of their median rate of whole-body insulin sensitivity.

The nature and potential risks of the study were explained to all subjects prior to obtaining their written informed consent. The study was carried out in accordance with the principles of the Declaration of Helsinki. The protocol was approved by the ethics committee of Helsinki University Central Hospital.

Whole-body insulin sensitivity Whole-body insulin sensitivity was measured using the insulin clamp technique [33]. The study was begun at 07:30 hours after an overnight fast. Two 18-gauge catheters (Venflon; Viggo-Spectramed, Helsingborg, Sweden) were inserted, one in an antecubital vein for infusion of insulin and glucose, and another retrogradely in a heated hand vein to obtain arterialised venous blood for measurement of glucose concentrations every $5 \mathrm{~min}$ and serum free insulin concentration every $30 \mathrm{~min}$. Regular human insulin (Insulin Actrapid; Novo Nordisk, Denmark) was infused in a primed-continuous fashion. The rate of the continuous insulin infusion was $1 \mathrm{mU} \mathrm{kg}^{-1} \mathrm{~min}^{-1}$ for $6 \mathrm{~h}$. Normoglycaemia was maintained by adjusting the rate of a $20 \%$ glucose infusion based on plasma glucose measurements from arterialised venous blood every $5 \mathrm{~min}$. Wholebody insulin sensitivity was determined from the glucose infusion rate required to maintain normoglycaemia between 30 and $360 \min$ [33].

Adipose tissue biopsy and total RNA cDNA preparation A needle aspiration biopsy of abdominal subcutaneous fat was taken under local intracutaneous anaesthesia at baseline and after 3 and $6 \mathrm{~h}$ of hyperinsulinaemia [34]. Each biopsy sample was taken from different locations in the left, middle and right lower abdominal region. The sample was immediately frozen and stored in liquid nitrogen until analysis. Frozen tissue samples $(50-150 \mathrm{mg})$ were homogenised in $2 \mathrm{ml}$ RNA STAT-60 (Tel-Test, Friendswood, TX, USA) and total RNA isolated according to the manufacturer's instructions. After DNase treatment (RNase-free DNase Set; Qiagen, Hilden, Germany) RNA was purified using the RNeasy Minikit (Qiagen). RNA concentrations were measured using the RiboGreen fluorescent nucleic acid stain (RNA Quantification Kit; Molecular Probes, Eugene, OR, USA). The quality of RNA was checked by agarose gel electrophoresis. Isolated RNA was stored at $-80^{\circ} \mathrm{C}$ until quantification of target mRNAs. A total of $0.1 \mu \mathrm{g}$ RNA was transcribed into cDNA using Moloney murine leukaemia virus reverse transcriptase (Life Technologies, Paisley, UK) and oligo $(\mathrm{dT})_{12-18}$ primers. 
Quantification of $m R N A$ concentrations Quantification of the gene encoding $\beta$-actin (ACTB), PPARG and ADIPOQ mRNA was performed in Helsinki (E.K.) by real-time PCR using LightCycler technology (Roche Diagnostics, Mannheim, Germany). An aliquot of $2 \mu \mathrm{l}$ 1:10 diluted cDNA was brought to a final volume of $20 \mu$ l, which contained $3 \mathrm{mmol} / \mathrm{l}$ magnesium chloride, $2 \mu \mathrm{l}$ LightCycler-FastStart DNA SYBR Green I Mix (Roche Diagnostics) and $0.5 \mu \mathrm{mol} / 1$ primers. After the initial activation of the DNA polymerase at $95^{\circ} \mathrm{C}$ for $10 \mathrm{~min}$, the amplification conditions were as follows: 40 cycles consisting of denaturation at $95^{\circ} \mathrm{C}$ for $15 \mathrm{~s}$, annealing for $5 \mathrm{~s}$ at $57^{\circ} \mathrm{C}(A C T B), 56^{\circ} \mathrm{C}$ $(P P A R G)$ and $58^{\circ} \mathrm{C}(A D I P O Q)$ and extension at $72^{\circ} \mathrm{C}$. The extension times (s) were calculated from the amplicon size $(\mathrm{bp} / 25)$. Fluorescent data were acquired at the end of each extension phase. After amplification, a melting curve analysis from $65^{\circ} \mathrm{C}$ to $95^{\circ} \mathrm{C}$ with a heating rate of $0.1^{\circ} \mathrm{C} / \mathrm{s}$ with a continuous fluorescence acquisition was made. The primers for PPARG, ADIPOQ and ACTB have been described [35]. A standard curve for PPARG was created using purified cloned plasmid cDNA (QIAquick PCR Purification Kit; Qiagen). For human $A C T B$ and $A D I P O Q$ expression, standard curves were created from a specific PCR product. To account for differences in RNA loading, $P P A R G$ and $A D I P O Q$ were expressed relative to $A C T B$.

The mRNA expression levels of facilitated glucose transporter, member 1 ( $S L C 2 A 1$, previously known as GLUT1), SLC2A4, PPARGC1A, TNF,HSD11B1 and the gene encoding TATA-box binding protein $(T B P)$ were measured in Stockholm (K.K., M.K., R.M.F.) using TaqMan real-time PCR according to the manufacturer's protocol using an ABI PRISM 7000 Sequence Detection System instrument and software (PE Applied Biosystems, Foster City, CA, USA). cDNA synthesised from 15 ng total RNA was mixed with TaqMan Universal PCR Master Mix (Applied Biosystems). Primer and probe sets for SLC2A1, SLC2A4, PPARGC1A and HSD11B1 were designed using the manufacturer's software and sequences available in GeneBank, and the sequences have been published previously $[35,36]$. Differences in the loading of cDNA were adjusted for by expressing results relative to TBP. Expression levels were quantified in arbitrary units by generating a sixpoint serial standard curve. After these analyses were performed, obese subjects were reported to have an excess of macrophages in adipose tissue $[8,9]$, and IL6 was shown to cause insulin resistance in adipocytes [11]. Therefore $C D 68$ and $I L 6$ were quantified later in remaining 0 - and 6-h samples and expressed relative to TBP. TNF,CD68, IL6 and TBP were measured using Pre-Developed TaqMan Assay Reagents (assay numbers Hs00174128 m1, Hs00154355 m1, Hs0 $0174131 \mathrm{ml}$ and Hs99999910 m1, respectively; Applied Biosystems). The specificity of each primer and probe set was confirmed by visualisation of a single PCR product by agarose gel electrophoresis.

Other measurements Blood samples were taken after an overnight fast for measurement of plasma glucose, serum insulin and C-peptide, serum triglyceride and total and HDL cholesterol concentrations. The percentage (\%) of body fat was determined by using bioelectrical impedance analysis (BioElectrical Impedance Analyzer System Model \#BIA-101A; RJL Systems, Detroit, MI, USA) [37]. Waist circumference was measured midway between spina iliaca superior and the lower rib margin, and hip circumference at the level of the greater trochanters [38].

Analytical procedures Plasma glucose concentrations were measured in duplicate with the glucose oxidase method (Glucose Analyzer II; Beckman Instruments, Fullerton, CA, USA) [39]. Serum free insulin concentrations were measured using the Auto-DELFIA kit from Wallac (Turku, Finland) and C-peptide concentrations by RIA [40]. $\mathrm{HbA}_{1} \mathrm{c}$ was measured by HPLC using the fully automated Glycosylated Hemoglobin Analyzer System (BioRad, Richmond, CA, USA) [41]. Serum total cholesterol, HDL cholesterol and triglyceride concentrations were measured with enzymatic kits from Roche Diagnostics using an autoanalyser (Roche Diagnostics Hitachi 917; Hitachi, Tokyo, Japan). LDL cholesterol concentration was calculated using the formula of Friedewald [42]. Serum adiponectin concentrations were measured using an ELISA kit from B-Bridge International (San Jose, CA, USA).
Table 1 Physical and biochemical characteristics of the study subjects divided into insulinsensitive and -resistant groups on the basis of their median whole-body insulin sensitivity

Data are means \pm SEM

\begin{tabular}{lccl}
\hline & Insulin-sensitive & Insulin-resistant & $p$ value \\
\hline Number & 11 & 10 & - \\
Age (years) & $32 \pm 3$ & $40 \pm 3$ & $\mathrm{NS}$ \\
Body weight (kg) & $69 \pm 4$ & $90 \pm 4$ & $<0.01$ \\
BMI (kg/m ${ }^{2}$ ) & $24.7 \pm 1.1$ & $32.7 \pm 1.8$ & $<0.001$ \\
Whole-body fat (\%) & $28 \pm 2$ & $36 \pm 1$ & $<0.001$ \\
Fat mass (kg) & $20 \pm 2$ & $35 \pm 4$ & $<0.01$ \\
Waist-to-hip-ratio & $0.86 \pm 0.01$ & $0.91 \pm 0.01$ & $<0.01$ \\
Fasting plasma glucose (mmol/l) & $5.1 \pm 0.1$ & $5.6 \pm 0.2$ & $<0.01$ \\
Fasting serum insulin (mU/l) & $3 \pm 1$ & $10 \pm 1$ & $<0.001$ \\
Fasting serum C-peptide (nmol/l) & $0.4 \pm 0.1$ & $0.8 \pm 0.1$ & $<0.001$ \\
Fasting serum LDL cholesterol (mmol/l) & $2.2 \pm 0.1$ & $3.1 \pm 0.1$ & $<0.01$ \\
Fasting serum triglycerides (mmol/l) & $0.8 \pm 0.1$ & $1.4 \pm 0.2$ & $<0.01$ \\
Fasting serum HDL cholesterol (mmol/l) & $1.4 \pm 0.1$ & $1.3 \pm 0.1$ & $<0.001$ \\
Fasting serum adiponectin (mg/l) & $18 \pm 2$ & $12 \pm 1$ & $<0.01$ \\
\hline
\end{tabular}


Statistical analyses All parameters were analysed using non-parametric methods. Insulin-sensitive and -resistant groups were compared using the Mann-Whitney test. Effects of insulin were analysed using Friedman's test followed by Dunn's post hoc test to compare single measurements. Correlations were calculated using Spearman's rank correlation coefficient. $p>0.05$ was considered statistically significant. The calculations were performed using SPSS 11.0 for Windows (SPSS, Chicago, IL, USA). All data are shown as means \pm SEM.

\section{Results}

Clinical characteristics Characteristics of the groups are given in Table 1. The insulin-resistant group was more obese than the insulin-sensitive group. Markers of insulin resistance, including serum fasting insulin, C-peptide and triglyceride concentrations were higher and HDL cholesterol and adiponectin concentrations were lower in the insulin-resistant than in the insulin-sensitive group.
Table 2 The relationship (Spearman's $r$ ) between gene expression in adipose tissue and whole-body insulin sensitivity

\begin{tabular}{|c|c|c|c|}
\hline Gene & $0 \mathrm{~h}$ & $3 \mathrm{~h}$ & $6 \mathrm{~h}$ \\
\hline$S L C 2 A 1 / T B P$ & -0.08 & -0.29 & 0.04 \\
\hline \multicolumn{4}{|c|}{ Insulin-sensitivity genes } \\
\hline$S L C 2 A 4 / T B P$ & $0.44^{\#}$ & $0.66^{* *}$ & $0.73 * * *$ \\
\hline$P P A R G / A C T B$ & 0.14 & -0.37 & -0.14 \\
\hline PPARGC1A/TBP & 0.19 & $0.55^{*}$ & 0.34 \\
\hline$A D I P O Q / A C T B$ & $0.48^{*}$ & -0.16 & -0.24 \\
\hline \multicolumn{4}{|c|}{ Insulin-resistance genes } \\
\hline$I L 6 / T B P$ & $-0.48^{*}$ & ND & $-0.71 * * *$ \\
\hline$T N F / T B P$ & $-0.44^{*}$ & $-0.53^{*}$ & $-0.46^{*}$ \\
\hline$H S D 11 B 1 / T B P$ & $-0.55^{*}$ & $-0.74 * * *$ & $-0.82 * * *$ \\
\hline \multicolumn{4}{|l|}{ Macrophage marker } \\
\hline$C D$ 68/TBP & $-0.66 * *$ & ND & $-0.68 * * *$ \\
\hline
\end{tabular}

$N D$ not determined

$* p<0.05$

$* * p<0.01$

$* * * p<0.001$

${ }^{\#} p=0.06$
Fig. 1 The expression of 'insulinsensitivity genes' $S L C 2 A 4$, $P P A R G, P P A R G C 1 A$ and $A D I P O Q$ in (a-d) insulin-sensitive $(n=11)$ and $(\mathbf{e}-\mathbf{h})$ insulin-resistant $(n=10)$ subjects at 0,3 and $6 \mathrm{~h}$ during euglycaemic hyperinsulinaemia (rate of continuous insulin infusion $1 \mathrm{mU} \mathrm{kg}^{-1} \mathrm{~min}^{-1}$ ). ${ }^{*} p<0.05,{ }^{*} p<0.01,{ }^{* * *} p<0.001$ for change between time points; $\# p<0.05, \# p<0.01$ for difference between groups
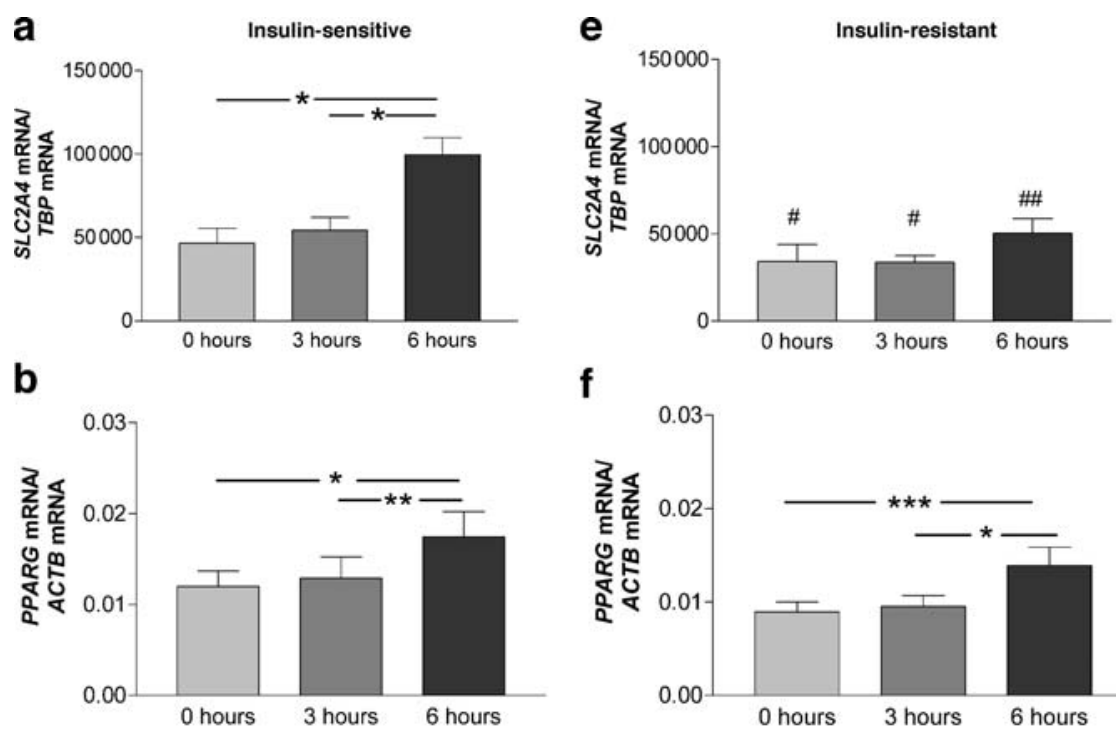

f

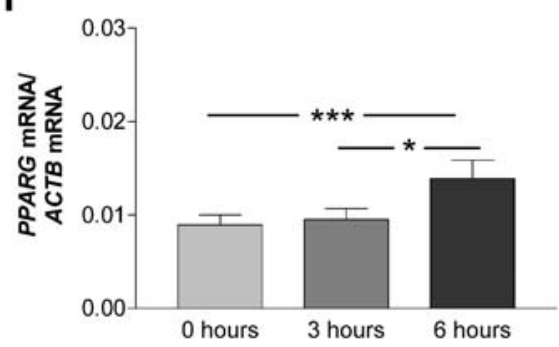

C

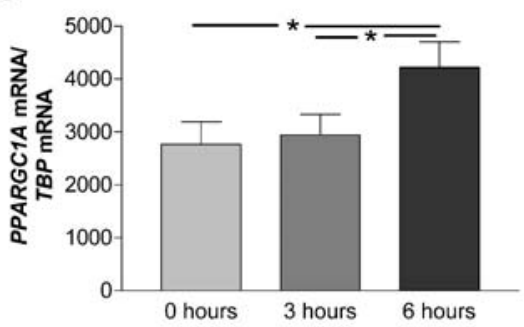

g

d

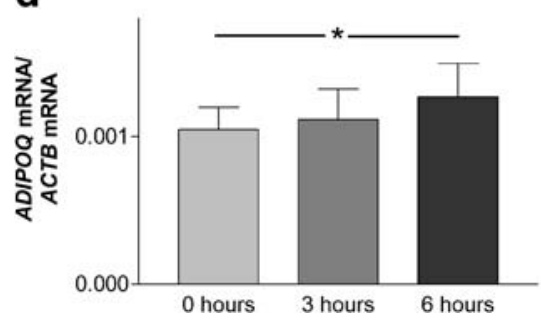

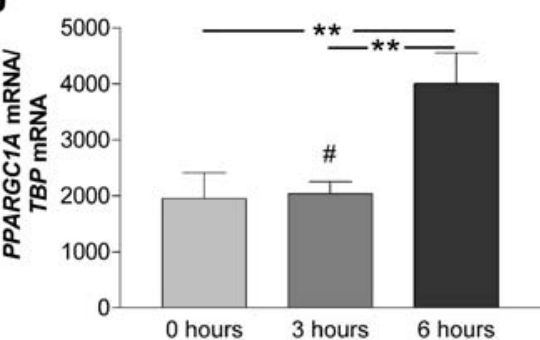

h

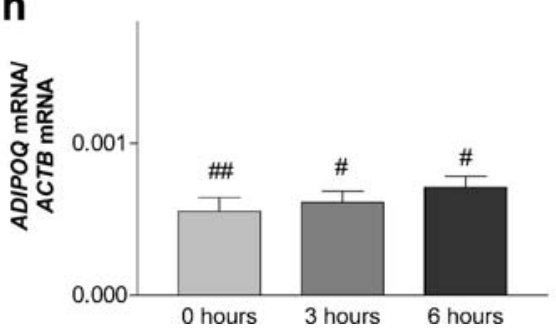


Fig. 2 The expression of 'insulinresistance genes' HSDIIB1 and $T N F$ in $(\mathbf{a}, \mathbf{b})$ insulin-sensitive $(n=11)$ and $(\mathbf{c}, \mathbf{d})$ insulin-resistant $(n=10)$ subjects at 0,3 and $6 \mathrm{~h}$ during euglycaemic hyperinsulinaemia (rate of continuous insulin infusion $1 \mathrm{mU} \mathrm{kg}^{-1} \mathrm{~min}^{-1}$ ). $* p<0.05$ for change between time points; $\# p<0.05, \# p<0.01$, $\# \# p<0.001$ for difference between groups
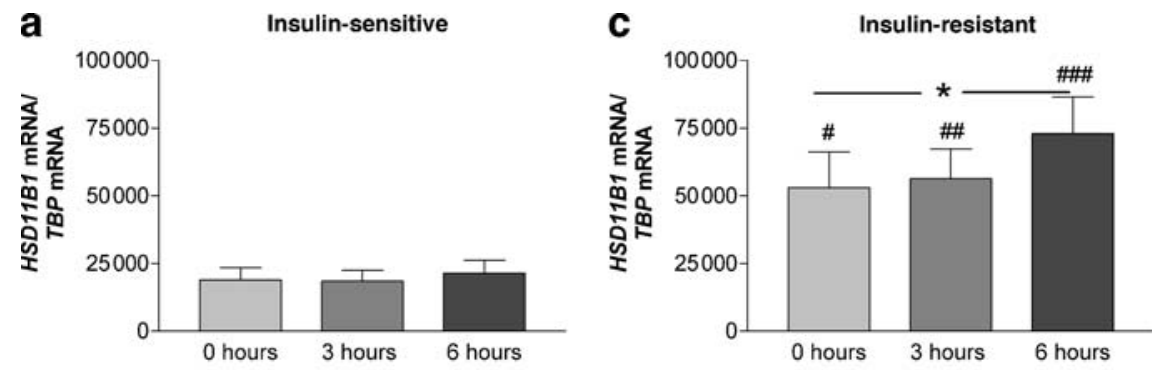

b

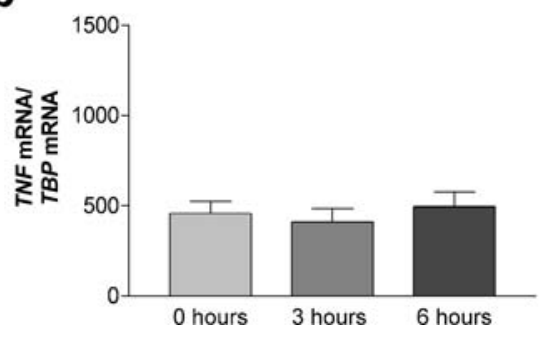

d

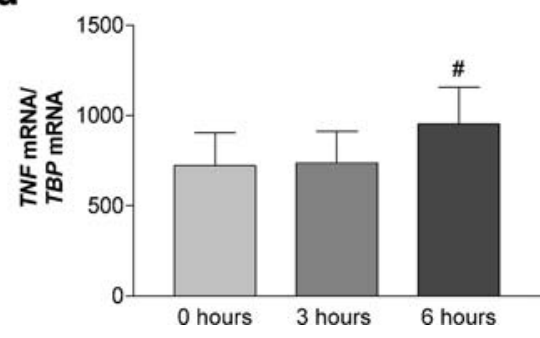

During the insulin infusion, serum insulin concentrations were similar in insulin-sensitive and -resistant groups ( $69 \pm 4$ vs $76 \pm 4 \mathrm{mU} / 1$, respectively; NS). By definition, wholebody insulin sensitivity was $107 \%$ higher in the insulinsensitive than the insulin-resistant group $(8.7 \pm 0.4$ vs $4.2 \pm$ $\left.0.3 \mathrm{mg} \mathrm{kg}^{-1} \mathrm{~min}^{-1}, p<0.0001\right)$.

Expression of genes encoding SLC2A1, SLC2A4, PPARG, PPARGC1A and ADIPOQ in adipose tissue Before the start of the insulin infusion, the mRNA concentrations of $S L C 2 A 1$ (1033 \pm 543 vs $722 \pm 251$, insulin-sensitive vs -resistant; NS), PPARG and PPARGC1A (Fig. 1) were comparable between the two groups. SLC2A4 gene expression was lower in the insulin-resistant than the insulin-sensitive group at baseline $(p<0.05)$. The mRNA concentrations of $S L C 2 A 1$ and the housekeeping genes $(A C T B$ and TBP) were comparable between the groups and remained unchanged during insulin infusion in both groups (data not shown). During the insulin infusion, SLC2A4 mRNA concentrations increased 2.2-fold in the insulin-sensitive group, whereas expression of $S L C 2 A 4$ remained unchanged in the insulinresistant group (Fig. 1). At $6 \mathrm{~h}, S L C 2 A 4$ expression was significantly higher in the insulin-sensitive than the insulinresistant group. In univariate correlation analysis (all subjects analysed as one group), SLC2A4 mRNA correlated with whole-body insulin sensitivity at $3 \mathrm{~h}$ (Spearman's $r=0.66$, $p<0.01)$ and $6 \mathrm{~h}(r=0.73, p<0.001)$ and almost significantly at $0 \mathrm{~h}$ (Table 2). The expression of PPARG and PPARGC1A increased significantly during insulin infusion in both groups with no differences between the groups (Fig. 1). PPARGC1A and SLC2A4 mRNA concentrations correlated with each other at $0 \mathrm{~h}(r=0.66, p<0.01)$ and $6 \mathrm{~h}(r=0.38, p<0.05)$. The changes in gene expression between 0 and $6 \mathrm{~h}$ of insulin infusion were confirmed in independent assays for the quantification of SLC2A4, PPARG and PPARGC1A (data not shown).

ADIPOQ gene expression at all time points was significantly higher in the insulin-sensitive than the insulinresistant group (Fig. 1). ADIPOQ mRNA concentrations increased significantly in the former but not in the latter group (Fig. 1). Serum adiponectin concentrations were significantly higher in the insulin-sensitive than the insulinresistant group before (Table 1) and during insulin infusion at $3 \mathrm{~h}(16 \pm 2$ vs $11 \pm 1 \mathrm{mg} / \mathrm{l}$, respectively; $p<0.01)$ and $6 \mathrm{~h}$ $(16 \pm 2$ vs $11 \pm 1 \mathrm{mg} / 1, p<0.01)$.
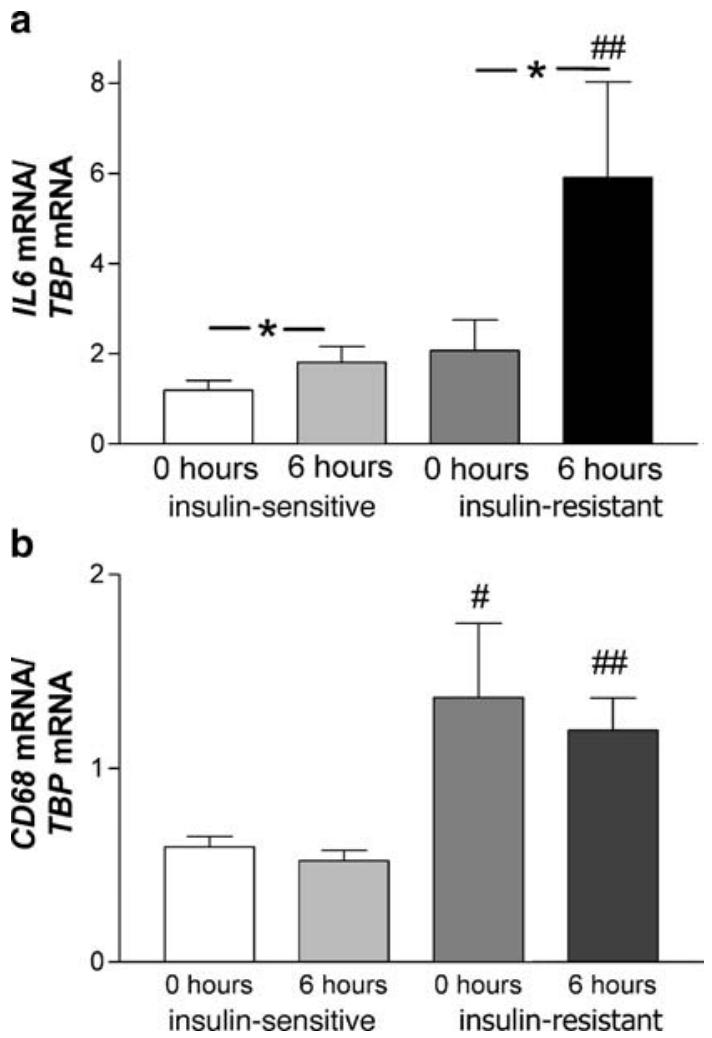

Fig. 3 The expression of (a) IL6 and (b) the macrophage marker $C D 68$ in insulin-sensitive and insulin-resistant subjects at 0 and $6 \mathrm{~h}$ during euglycaemic hyperinsulinaemia (rate of continuous insulin infusion $1 \mathrm{mU} \mathrm{kg}^{-1} \mathrm{~min}^{-1}$ ). ${ }^{*} p<0.05$ for change between time points; $\# p<0.05, \# \# p<0.01$ for difference between groups 
HSD11B1, TNF and IL6 Before insulin infusion, HSD11B1 mRNA concentrations were 2.4-fold higher in the insulinresistant than the insulin-sensitive group (Fig. 2). Insulin further increased $H S D 11 B 1 \mathrm{mRNA}$ concentrations in the former group, while there were no changes in the insulinsensitive group. TNF mRNA concentrations tended to be higher in the insulin-resistant than the insulin-sensitive group at all time points with a significant difference at $6 \mathrm{~h}$ (Fig. 2). Insulin did not change TNF concentrations significantly. IL6 gene expression increased by insulin in both groups and expression was significantly higher in the insulin-resistant than in the insulin-sensitive group at $6 \mathrm{~h}$ (Fig. 3). Also, the increase in IL 6 gene expression by insulin was significantly higher in the insulin-resistant than the insulin-sensitive group $(p<0.02)$.

Expression of macrophage marker CD68 Before and during the insulin infusion, $C D 68$ mRNA concentrations were significantly higher in the insulin-resistant than the insulin-sensitive group (Fig. 3).

\section{Discussion}

The present data are the first to compare the responses of genes thought to counteract insulin action ('insulin-resistance genes') and enhance insulin action ('insulin-sensitivity genes') to insulin in vivo in adipose tissue. The study was performed in apparently healthy subjects (except for obesity) who were arbitrarily divided into less insulin-sensitive (insulin-resistant group) and more insulin-sensitive (insulinsensitive group) based on their median whole-body insulin sensitivity. The results show that insulin resistance is not only characterised by failure of insulin to normally increase expression of 'insulin-sensitivity genes' (SLC2A4, ADI $P O Q$ ) but also by hyperresponsiveness of 'insulin-resistance genes' (IL6, HSD11B1, TNF) to insulin.

The multitude of genes involved in regulating insulin action and the discovery that adipose tissue of obese subjects contains an excess of macrophages [8], which also express insulin-action genes, makes interpretation of the present data complex. Because of the need for repeated biopsies, it was unfeasible to take enough adipose tissue to allow separation of macrophages and adipose cells, and therefore we were unable to allocate the observed changes in gene expression to a given cell type. Theoretically, this implies that any of the following scenarios might have taken place. Firstly, genes hyperresponding to insulin could reside in a different cell type than those hyporesponding to insulin. For example, the hyperresponse to insulin of IL6, which is expressed both in macrophages and in adipocytes, could have occurred in macrophages and the hyporesponse of adiponectin in adipocytes, which is the only cell type expressing adiponectin [43]. Secondly, both the hyper- and hyporesponse could have occurred in the same cell type but the increased basal or insulin-stimulated expression of 'insulin-resistance genes' in the insulin-resistant group could have modulated the response to insulin. Thirdly, a combination of both mechanisms might have been involved. These possibilities will be further discussed below in conjunction with the individual genes.

We divided the present study subjects on the basis of their whole-body insulin sensitivity. As expected the insulin-resistant subjects were more obese and had more whole-body fat than the insulin-sensitive subjects. We cannot therefore distinguish between effects of obesity as compared with insulin sensitivity on gene expression in adipose tissue. Adipocyte cell size is increased in insulinresistant obese subjects and may influence adipose gene expression [44]. There are abundant, albeit controversial, data on differences in gene expression between different adipose tissue depots [45]. Repeated sampling of intraabdominal fat was not ethically justifiable in healthy subjects.

Several previous studies have compared expression of one or several of the genes in the basal state, i.e. after an overnight fast, between non-obese insulin-sensitive and obese insulin-resistant subjects. These include reports of decreased expression of the 'insulin-sensitivity genes' SLC2A4 [20, 46, 47], PPARGC1A [23] and ADIPOQ [16, 48]. These findings were confirmed in the present study. Deletion or overexpression of each of these genes has been shown to modulate insulin action in mouse models [21, 4952]. Data are inconsistent regarding $P P A R G$, with reports of decreased $[53,54]$ or unchanged $[55,56]$ expression of the gene encoding PPARG1, and decreased [57], unchanged $[53,55]$ or increased $[54,56]$ expression of the gene encoding PPARG2 in obese as compared with lean subjects. The relative abundance of the mRNAs of PPARG1 and PPARG2 is also controversial [32, 55-57]. In the present study, PPARG expression was comparable between the insulin-resistant and the insulin-sensitive group (Fig. 1). Regarding expression of the 'insulin-resistance genes', we confirm reports of increased basal expression of HSD $11 B 1$ $[58,59]$. In addition, at $6 \mathrm{~h}$ of insulin infusion gene expression of TNF and IL 6 was greater in the insulin-resistant than in the insulin-sensitive group (Figs. 2 and 3).

Regarding acute regulation of gene expression by insulin, the present data are, to the best of our knowledge, novel in comparing acute changes in gene expression in insulin-sensitive and -resistant subjects and in demonstrating that insulin increases mRNA concentrations of HSD11B1 and PPARGC1A in human adipose tissue in vivo. Previous studies have shown that insulin increases $S L C 2 A 4$ expression in skeletal muscle $[30,60]$, and that this effect is blunted in skeletal muscle in insulin-resistant as compared with insulin-sensitive subjects $[30,60]$. This was confirmed in adipose tissue in the present study. PPARGC1A is a transcriptional coactivator, which induces gene expression of SLC2A4 in skeletal muscle [61]. It is absent from white adipose tissue in mice but is expressed in human adipose tissue [23]. We confirm the presence of PPARGC1A in human adipose tissue [23] and extend previous findings by demonstrating that insulin acutely increases PPARGC1A expression in vivo. PPARGC1A and SLC2A4 expression was significantly correlated, which is in keeping with data showing that overexpression of PPARGC1A in skeletal muscle increases $S L C 2 A 4$ content and insulin sensitivity 
[24]. Overexpression of PPARGC1A increases energy expenditure by stimulating thermogenesis in brown fat in mice [62]. This increases the need for fuels such as glucose. Increases in gluconeogenesis in the liver and glucose utilisation in peripheral tissues by PPARGC1A could help to maintain energy supply, even if regulated in a tissuespecific fashion by insulin. Insulin has been shown to acutely (i.e. within $3 \mathrm{~h}$ ) increase expression of PPARG, but the response was similar in lean and obese subjects and in type 2 diabetic patients [32]. In the present study, we also found that $P P A R G$ gene expression responded similarly to insulin in both groups studied (Fig. 1).

Regarding 'insulin-resistance genes', HSD11B1 was higher at all time points in the insulin-resistant as compared with the insulin-sensitive group, and increased in response to insulin in the former but not in the latter group (Fig. 2). Data regarding insulin regulation of $H S D 11 B 1$ gene expression and activity are not unequivocal. In preadipocytes, insulin attenuates HSD11B1 activity but synergises with glucocorticoids to stimulate adipocyte differentiation that is associated with induction of HSD11B1 activity [63]. In vivo, consistent with the present data at the $3 \mathrm{~h}$ time point, $3 \mathrm{~h}$ of hyperinsulinaemia has been reported not to change HSD11 $B 1$ expression in type 2 diabetic or healthy men [28]. $H S D 11 B 1$ is a gene that is abundantly expressed in macrophages in addition to adipocytes [14]. Therefore the increase in HSD11B1 in the insulin-resistant group could also be due to insulin action in macrophages, although this possibility remains hypothetical. Like HSD11B1, IL6 was increased significantly more by insulin in the insulinresistant than the insulin-sensitive subjects (Fig. 3). This most probably occurred in non-adipose cells, since isolated adipocytes account for only $10 \%$ of total IL6 release from human adipose tissue [4]. IL6 may antagonise insulin action [1] by several mechanisms. It has been shown to downregulate $S L C 2 A 4, P P A R G$ and ADIPOQ expression in 3T3$\mathrm{L} 1$ adipocytes $[11,64,65]$, and increase HSD11B1 activity in primary cultures of adipose stromal cells [66]. The interstitial IL6 concentration in human adipose tissue is $\sim 100$ times higher than that in plasma [67] and IL6, in contrast to TNF, is released from adipose tissue systemically [3]. The high local concentration of IL6 and the existence of all components important for IL6 signalling in human fat cells suggest that IL6 originating from non-fat cells in part induces insulin resistance in a paracrine fashion [11].

$T N F$ expression after $6 \mathrm{~h}$ of insulin infusion was higher in insulin-resistant than in insulin-sensitive subjects. Two recent studies have found virtually all TNF to be derived from macrophages [9] or non-fat cells [68] in human adipose tissue. In a study examining the direct effect of insulin on macrophage gene expression using an array technique, insulin stimulated TNF the most among all genes in the analysis [69]. In an earlier study, lipopolysaccharide was found to increase TNF production more robustly from human whole-adipose tissue than from isolated adipocytes [29]. In the latter study, insulin had no effect on TNFproduction. In a study that also used the insulin clamp technique and measured $T N F$ expression in a group of normal subjects, insulin was found to increase $T N F$ expression in adipose tissue transiently after $2 \mathrm{~h}$ [27]. In another study, $4 \mathrm{~h}$ of in vivo hyperinsulinaemia had no effect on subcutaneous adipose tissue TNF mRNA concentration in lean or obese subjects [28]. Our data suggest that the response of $T N F$ to insulin is exaggerated in insulin-resistant subjects, although the increase by insulin failed to reach statistical significance. Whether this is because an increased number of macrophages (vide infra) hyperrespond to insulin remains to be determined.

In the study reporting macrophage accumulation in adipose tissue in obesity, immunohistochemical detection and quantification of $C D 68$-expressing cells in subcutaneous adipose tissue showed that average adipocyte size and BMI were strong predictors of $C D 68$-expressing cells [9]. The increase in the present study of $C D 68$ expression in insulinresistant obese subjects therefore most probably reflects an increase in the number of macrophages in adipose tissue.

$A D I P O Q$ mRNA concentration increased significantly by $6 \mathrm{~h}$ in the insulin-sensitive but not the insulin-resistant group (Fig. 1). ADIPOQ expression has been studied in two previous in vivo studies, which found no change after $2.5 \mathrm{~h} \mathrm{[48]} \mathrm{and} 3 \mathrm{~h} \mathrm{[28]} \mathrm{of} \mathrm{insulin} \mathrm{infusion,} \mathrm{consistent} \mathrm{with}$ the present data after $3 \mathrm{~h}$. In vitro, in 3T3-L1 adipocytes, insulin has been reported both to increase [70] and decrease [71] adiponectin expression. In human adipocytes, insulin has been reported to increase adiponectin secretion from omental but not subcutaneous adipocytes [72].

We conclude that acute insulin regulation of gene expression in insulin-resistant adipose tissue is characterised not only by hyporesponsiveness of insulin-sensitivity genes such as $S L C 2 A 4$ to insulin but also by hyperresponsiveness of insulin-resistance genes (IL6, TNF, HSDI1B1). Although attempts made to date in humans using antiinflammatory approaches such as TNF antagonists to ameliorate insulin resistance have been unsuccessful, the present study supports continued development of such therapies.

Acknowledgements We gratefully acknowledge Ms Katja Tuominen and Mia Urjansson for excellent technical assistance. The study was supported by grants from the Academy of Finland (J. Westerbacka, H. Yki-Järvinen), the Sigrid Juselius (H. Yki-Järvinen) and EVO (J. Westerbacka, H. Yki-Järvinen) foundations, the Karolinska Institute (A. Hamsten) and the Swedish Heart-Lung Foundation (A. Hamsten).

\section{References}

1. Vozarova B, Weyer C, Hanson K, Tataranni PA, Bogardus C, Pratley RE (2001) Circulating interleukin-6 in relation to adiposity, insulin action, and insulin secretion. Obes Res 9:414-417

2. Kern PA, Ranganathan S, Li C, Wood L, Ranganathan G (2001) Adipose tissue tumor necrosis factor and interleukin-6 expression in human obesity and insulin resistance. Am J Physiol Endocrinol Metab 280:E745-E751

3. Mohamed-Ali V, Goodrick S, Rawesh A et al. (1997) Subcutaneous adipose tissue releases interleukin-6, but not tumor necrosis factor-alpha, in vivo. J Clin Endocrinol Metab $82: 4196-4200$ 
4. Fried SK, Bunkin DA, Greenberg AS (1998) Omental and subcutaneous adipose tissues of obese subjects release interleukin-6: depot difference and regulation by glucocorticoid. $\mathrm{J}$ Clin Endocrinol Metab 83:847-850

5. Straub RH, Hense HW, Andus T, Scholmerich J, Riegger GA, Schunkert H (2000) Hormone replacement therapy and interrelation between serum interleukin- 6 and body mass index in postmenopausal women: a population-based study. J Clin Endocrinol Metab 85:1340-1344

6. Maachi M, Pieroni L, Bruckert E et al. (2004) Systemic lowgrade inflammation is related to both circulating and adipose tissue TNFalpha, leptin and IL-6 levels in obese women. Int J Obes Relat Metab Disord 28:993-997

7. Hotamisligil GS, Arner P, Caro JF, Atkinson RL, Spiegelman BM (1995) Increased adipose tissue expression of tumor necrosis factor-alpha in human obesity and insulin resistance. J Clin Invest 95:2409-2415

8. Xu H, Barnes GT, Yang Q et al. (2003) Chronic inflammation in fat plays a crucial role in the development of obesity-related insulin resistance. J Clin Invest 112:1821-1830

9. Weisberg SP, McCann D, Desai M, Rosenbaum M, Leibel RL, Ferrante AWJ (2003) Obesity is associated with macrophage accumulation in adipose tissue. J Clin Invest 112:1796-1808

10. Kannisto K, Sutinen J, Korsheninnikova E et al. (2003) Expression of adipogenic transcription factors, peroxisome proliferator-activated receptor gamma co-activator 1, IL-6 and CD45 in subcutaneous adipose tissue in lipodystrophy associated with highly active antiretroviral therapy. AIDS $17: 1753-1762$

11. Rotter V, Nagaev I, Smith U (2003) Interleukin-6 (IL-6) induces insulin resistance in 3T3-L1 adipocytes and is, like IL8 and tumor necrosis factor-alpha, overexpressed in human fat cells from insulin-resistant subjects. J Biol Chem 278:4577745784

12. Bastard JP, Maachi M, Van Nhieu JT et al. (2002) Adipose tissue IL-6 content correlates with resistance to insulin activation of glucose uptake both in vivo and in vitro. J Clin Endocrinol Metab 87:2084-2089

13. Napolitano A, Voice MW, Edwards CR, Seckl JR, Chapman KE (1998) 11Beta-hydroxysteroid dehydrogenase 1 in adipocytes: expression is differentiation-dependent and hormonally regulated. J Steroid Biochem Mol Biol 64:251-260

14. Thieringer R, Le Grand CB, Carbin L et al. (2001) 11 Betahydroxysteroid dehydrogenase type 1 is induced in human monocytes upon differentiation to macrophages. J Immunol $167: 30-35$

15. Paterson JM, Morton NM, Fievet C et al. (2004) Metabolic syndrome without obesity: hepatic overexpression of 11 betahydroxysteroid dehydrogenase type 1 in transgenic mice. Proc Natl Acad Sci USA 101:7088-7093

16. Hu E, Liang P, Spiegelman BM (1996) AdipoQ is a novel adipose-specific gene dysregulated in obesity. J Biol Chem 271:10697-10703

17. Weyer C, Funahashi T, Tanaka S et al. (2001) Hypoadiponectinemia in obesity and type 2 diabetes: close association with insulin resistance and hyperinsulinemia. J Clin Endocrinol Metab 86:1930-1935

18. Arita Y, Kihara S, Ouchi N et al. (1999) Paradoxical decrease of an adipose-specific protein, adiponectin, in obesity. Biochem Biophys Res Commun 257:79-83

19. Sutinen J, Korsheninnikova E, Funahashi T, Matsuzawa Y, Nyman T, Yki-Jarvinen H (2003) Circulating concentration of adiponectin and its expression in subcutaneous adipose tissue in patients with highly active antiretroviral therapy-associated lipodystrophy. J Clin Endocrinol Metab 88:1907-1910

20. Garvey WT, Maianu L, Huecksteadt TP, Birnbaum MJ, Molina JM, Ciaraldi TP (1991) Pretranslational suppression of a glucose transporter protein causes insulin resistance in adipocytes from patients with non-insulin-dependent diabetes mellitus and obesity. J Clin Invest 87:1072-1081
21. He W, Barak Y, Hevener A et al. (2003) Adipose-specific peroxisome proliferator-activated receptor gamma knockout causes insulin resistance in fat and liver but not in muscle. Proc Natl Acad Sci USA 100:15712-15717

22. Hevener AL, He W, Barak Y et al. (2003) Muscle-specific PPAR $\gamma$ deletion causes insulin resistance. Nat Med 9:14911497

23. Hammarstedt A, Jansson PA, Wesslau C, Yang X, Smith U (2003) Reduced expression of PGC-1 and insulin-signaling molecules in adipose tissue is associated with insulin resistance. Biochem Biophys Res Commun 301:578-582

24. Michael LF, Wu Z, Cheatham RB et al. (2001) Restoration of insulin-sensitive glucose transporter (GLUT4) gene expression in muscle cells by the transcriptional coactivator PGC-1. Proc Natl Acad Sci USA 98:3820-3825

25. Vicennati V, Vottero A, Friedman C, Papanicolaou DA (2002) Hormonal regulation of interleukin-6 production in human adipocytes. Int J Obes Relat Metab Disord 26:905-911

26. Fasshauer M, Klein J, Lossner U, Paschke R (2003) Interleukin (IL)-6 mRNA expression is stimulated by insulin, isoproterenol, tumour necrosis factor alpha, growth hormone, and IL-6 in 3T3-L1 adipocytes. Horm Metab Res 35:147-152

27. Krogh-Madsen R, Plomgaard P, Keller P, Keller C, Pedersen BK (2004) Insulin stimulates interleukin-6 and tumor necrosis factor-alpha gene expression in human subcutaneous adipose tissue. Am J Physiol Endocrinol Metab 286:E234-E238

28. Koistinen HA, Forsgren M, Wallberg-Henriksson H, Zierath JR (2004) Insulin action on expression of novel adipose genes in healthy and type 2 diabetic subjects. Obes Res 12:25-31

29. Sewter CP, Digby JE, Blows F, Prins J, O'Rahilly S (1999) Regulation of tumour necrosis factor-alpha release from human adipose tissue in vitro. J Endocrinol 163:33-38

30. Schalin-Jäntti C, Yki-Järvinen H, Koranyi L et al. (1994) Effect of insulin on GLUT-4 mRNA and protein concentrations in skeletal muscle of patients with NIDDM and their first-degree relatives. Diabetologia 37:401-407

31. Vidal H, Auboeuf D, De Vos P et al. (1996) The expression of $o b$ gene is not acutely regulated by insulin and fasting in human abdominal subcutaneous adipose tissue. J Clin Invest 98:251255

32. Rieusset J, Andreelli F, Auboeuf D et al. (1999) Insulin acutely regulates the expression of the peroxisome proliferatoractivated receptor-gamma in human adipocytes. Diabetes 48:699-705

33. DeFronzo RA, Tobin JD, Andres R (1979) Glucose clamp technique: a method for quantifying insulin secretion and resistance. Am J Physiol 237:E214-E223

34. Yki-Järvinen H, Nikkilä EA, Kubo K, Foley JE (1986) Assay of glucose transport in human fat cells obtained by needle biopsy. Diabetologia 29:287-290

35. Sutinen J, Kannisto K, Korsheninnikova E et al. (2004) Effects of rosiglitazone on gene expression in subcutaneous adipose tissue in highly active antiretroviral therapy-associated lipodystrophy. Am J Physiol Endocrinol Metab 286:E941-E949

36. Kannisto K, Pietilainen KH, Ehrenborg E et al. (2004) Overexpression of 11 beta-hydroxysteroid dehydrogenase- 1 in adipose tissue is associated with acquired obesity and features of insulin resistance: studies in young adult monozygotic twins. J Clin Endocrinol Metab 89:4414-4421

37. Lukaski HC, Johnson PE, Bolonchuk WW, Lykken GI (1985) Assessment of fat-free mass using bioelectrical impedance measurements of the human body. Am J Clin Nutr 41:810-817

38. Marti B, Tuomilehto J, Salomaa V, Kartovaara L, Korhonen HJ, Pietinen P (1991) Body fat distribution in the Finnish population: environmental determinants and predictive power for cardiovascular risk factor levels. J Epidemiol Community Health 45:131-137

39. Kadish AH, Little RL, Sternberg JC (1968) A new and rapid method for the determination of glucose by measurement of rate of oxygen consumption. Clin Chem 14:116-131 
40. Kuzuya H, Blix PM, Horwitz DL, Steiner DF, Rubenstein AH (1977) Determination of free and total insulin and C-peptide in insulin-treated diabetics. Diabetes 26:22-29

41. Stenman U-H, Pesonen K, Ylinen K, Huhtala ML, Teramo K (1984) Rapid chromatographic quantitation of glycosylated haemoglobins. J Chromatogr 297:327-332

42. Friedewald WT, Levy RI, Fredrickson DS (1972) Estimation of the concentration of low-density lipoprotein cholesterol in plasma, without use of the preparative ultracentrifuge. Clin Chem 18:499-502

43. Maeda K, Okubo K, Shimomura I, Funahashi T, Matsuzawa Y, Matsubara K (1996) cDNA cloning and expression of a novel adipose specific collagen-like factor, apM1 (AdiPose Most abundant Gene transcript 1). Biochem Biophys Res Commun 221:286-289

44. Coppack SW (2001) Pro-inflammatory cytokines and adipose tissue. Proc Nutr Soc 60:349-356

45. Vidal H (2001) Gene expression in visceral and subcutaneous adipose tissues. Ann Med 33:547-555

46. Giacchetti G, Faloia E, Taccaliti A et al. (1994) Decreased expression of insulin-sensitive glucose transporter mRNA (GLUT-4) in adipose tissue of non-insulin-dependent diabetic and obese patients: evaluation by a simplified quantitative PCR assay. J Endocrinol Invest 17:709-715

47. Carvalho E, Jansson PA, Nagaev I, Wenthzel AM, Smith U (2001) Insulin resistance with low cellular IRS-1 expression is also associated with low GLUT4 expression and impaired insulin-stimulated glucose transport. FASEB J 15:1101-1103

48. Lihn AS, Ostergard T, Nyholm B, Pedersen SB, Richelsen B, Schmitz O (2003) Adiponectin expression in adipose tissue is reduced in first-degree relatives of type 2 diabetic patients. Am J Physiol Endocrinol Metab 284:E443-E448

49. Marshall BA, Mueckler MM (1994) Differential effects of GLUT-1 or GLUT-4 overexpression on insulin responsiveness in transgenic mice. Am J Physiol 267:E738-E744

50. Tozzo E, Shepherd PR, Gnudi L, Kahn BB (1995) Transgenic GLUT-4 overexpression in fat enhances glucose metabolism: preferential effect on fatty acid synthesis. Am J Physiol 268: E956-E964

51. Maeda N, Shimomura I, Kishida K et al. (2002) Diet-induced insulin resistance in mice lacking adiponectin/ACRP30. Nat Med 8:731-737

52. Koo SH, Satoh H, Herzig S et al. (2004) PGC-1 promotes insulin resistance in liver through PPAR-alpha-dependent induction of TRB-3. Nat Med 10:530-534

53. Yang X, Enerback S, Smith U (2003) Reduced expression of FOXC2 and brown adipogenic genes in human subjects with insulin resistance. Obes Res 11:1182-1191

54. Sewter C, Blows F, Considine R, Vidal-Puig A, O'Rahilly S (2002) Differential effects of adiposity on peroxisomal proliferator-activated receptor gamma1 and gamma2 messenger ribonucleic acid expression in human adipocytes. J Clin Endocrinol Metab 87:4203-4207

55. Auboeuf D, Rieusset J, Fajas L et al. (1997) Tissue distribution and quantification of the expression of mRNAs of peroxisome proliferator-activated receptors and liver $\mathrm{X}$ receptor-alpha in humans: no alteration in adipose tissue of obese and NIDDM patients. Diabetes 46:1319-1327

56. Vidal-Puig AJ, Considine RV, Jimenez-Linan M et al. (1997) Peroxisome proliferator-activated receptor gene expression in human tissues. Effects of obesity, weight loss, and regulation by insulin and glucocorticoids. J Clin Invest 99:2416-2422
57. Giusti V, Verdumo C, Suter M, Gaillard RC, Burckhardt P, Pralong F (2003) Expression of peroxisome proliferatoractivated receptor-gammal and peroxisome proliferator-activated receptor-gamma2 in visceral and subcutaneous adipose tissue of obese women. Diabetes 52:1673-1676

58. Stewart PM, Boulton A, Kumar S, Clark PM, Shackleton CH (1999) Cortisol metabolism in human obesity: impaired cortisone $\rightarrow$ cortisol conversion in subjects with central adiposity. J Clin Endocrinol Metab 84:1022-1027

59. Paulmyer-Lacroix O, Boullu S, Oliver C, Alessi MC, Grino M (2002) Expression of the mRNA coding for 11beta-hydroxysteroid dehydrogenase type 1 in adipose tissue from obese patients: an in situ hybridization study. J Clin Endocrinol Metab 87:2701-2705

60. Andersen PH, Lund S, Vestergaard H, Junker S, Kahn BB, Pedersen O (1993) Expression of the major insulin regulatable glucose transporter (GLUT4) in skeletal muscle of noninsulindependent diabetic patients and healthy subjects before and after insulin infusion. J Clin Endocrinol Metab 77:27-32

61. Puigserver P, Spiegelman BM (2003) Peroxisome proliferatoractivated receptor-gamma coactivator 1 alpha (PGC-1 alpha): transcriptional coactivator and metabolic regulator. Endocr Rev 24:78-90

62. Lin J, Wu H, Tarr PT et al. (2002) Transcriptional co-activator PGC-1 alpha drives the formation of slow-twitch muscle fibres. Nature 418:797-801

63. Stulnig TM, Waldhausl W (2004) 11beta-Hydroxysteroid dehydrogenase type 1 in obesity and type 2 diabetes. Diabetologia 47:1-11

64. Bruun JM, Lihn AS, Verdich C et al. (2003) Regulation of adiponectin by adipose tissue-derived cytokines: in vivo and in vitro investigations in humans. Am J Physiol Endocrinol Metab 285:E527-E533

65. Fasshauer M, Kralisch S, Klier M et al. (2003) Adiponectin gene expression and secretion is inhibited by interleukin- 6 in 3T3-L1 adipocytes. Biochem Biophys Res Commun 301: $1045-1050$

66. Tomlinson JW, Moore J, Cooper MS et al. (2001) Regulation of expression of 11 beta-hydroxysteroid dehydrogenase type 1 in adipose tissue: tissue-specific induction by cytokines. Endocrinology 142:1982-1989

67. Sopasakis VR, Sandqvist M, Gustafson B et al. (2004) High local concentrations and effects on differentiation implicate interleukin-6 as a paracrine regulator. Obes Res 12:454-460

68. Fain JN, Bahouth SW, Madan AK (2004) TNFalpha release by the nonfat cells of human adipose tissue. Int J Obes Relat Metab Disord 28:616-622

69. Iida KT, Shimano H, Kawakami Y et al. (2001) Insulin upregulates tumor necrosis factor-alpha production in macrophages through an extracellular-regulated kinase-dependent pathway. J Biol Chem 276:32531-32537

70. Scherer PE, Williams S, Fogliano M, Baldini G, Lodish HF (1995) A novel serum protein similar to $\mathrm{Clq}$, produced exclusively in adipocytes. J Biol Chem 270:26746-26749

71. Fasshauer M, Klein J, Neumann S, Eszlinger M, Paschke R (2002) Hormonal regulation of adiponectin gene expression in 3T3-L1 adipocytes. Biochem Biophys Res Commun 290:1084-1089

72. Motoshima H, Wu X, Sinha MK et al. (2002) Differential regulation of adiponectin secretion from cultured human omental and subcutaneous adipocytes: effects of insulin and rosiglitazone. J Clin Endocrinol Metab 87:5662-5667 